\title{
PRODUCTION OF HYDROLYTIC ENZYMES BY THE PLANT PATHOGENIC FUNGUS MYROTHECIUM VERRUCARIA IN SUBMERGED CULTURES
}

\author{
Fabiana Guillen Moreira; Simone dos Reis; Maria Aparecida Ferreira Costa; Cristina Giatti Marques de Souza; \\ Rosane Marina Peralta*
}

Laboratório de Bioquímica e Fisiologia de Microrganismos, Departamento de Bioquímica, Universidade Estadual de Maringá, Maringá, PR, Brasil

Submitted: September 23, 2003; Returned to authors for corrections: January 27, 2004; Approved: December 20, 2004

\begin{abstract}
The capability of the plant pathogenic fungus Myrothecium verrucaria to produce extracellular hydrolytic enzymes in submerged cultures was studied using several substrates. The fungus was able to produce different depolymerases and glycosidases, being xylanase, pectinase and protease the most important. Lipase was found in cultures developed in the presence of olive oil, while protease activity was detected in all cultures. Xylanase and pectinase were optimally active at $\mathrm{pH} 4.5-5.5$, while protease was active in a large range of $\mathrm{pH} 3.5$ to 11.0. All three enzymes were maximally active at $40^{\circ} \mathrm{C}$ and they were stable for several hours at temperature up to $50^{\circ} \mathrm{C}$.
\end{abstract}

Key words: carbohydrases, hydrolytic enzymes, Myrothecium verrucaria, protease

\section{INTRODUCTION}

Plant pathogens produce a range of enzymes capable of degrading plant cell wall components $(1,23)$. Among the economically important plant pathogens, Myrothecium verrucaria (Albertini and Schwein) Ditmar:Fr, is a ubiquitous phytopathogenic fungus which attacks a wide range of plants, including cucumber (20), soybean (16), upland cotton (11), sunflower (3), birdsfoot trefoil (6), tomato (25), rice (24) and corn (27).

Extracellular proteins secreted by fungus are able to macerate tissues and degrade cell wall components. They must thus contain the enzymes corresponding to the types of glycosidic linkages present in the cell wall polysaccharides. Extracellular enzymes are important to fungi not only for digestion but also in many instances for the pathogenic process: the enzymes may function in overcoming the natural resistance of the host as well as in providing soluble products that can be absorbed and used as food (9). M. verrucaria is known to produce endochitinase $(8,26)$, xylanases $(7)$, pectinases $(5)$ and bilirrubin oxidases (10). The production of extracellular proteases by plant pathogenic fungi is also well documented, and it has been proposed that in some fungus-plant interactions these enzymes may function as pathogenic factors $(4,17,19,20,23)$.

Studies of enzyme production by a phytopathogenic fungus are complicated by the presence of plant, particularly by the presence of plant enzymes and microbial enzyme inhibitors that occur in the plants. The most practical way to study the production of enzyme by a fungus is therefore to study the production of its enzymes on artificial growth media that contain no plant or enzyme inhibitors produced by the plant. Considering that, the aim of this study was to get an overview of the enzymes that are produced by $M$. verrucaria in submerged cultures possibly involved with its phytopathogenicity.

\section{MATERIALS AND METHODS}

\section{Microorganism \\ Myrothecium verrucaria (Albertini and Schwein) Ditmar:Fr CCT 1886 was obtained from the Collection culture of Fundação André Tosello, Campinas, SP, Brazil and it was maintained on potato dextrose agar.}

*Corresponding Author. Mailing address: Universidade Estadual de Maringá, Departamento de Bioquímica, Avenida Colombo, 5790, Zona 07. 87020900, Maringá, PR, Brasil. E-mail: rmperalta@uem.br 


\section{Enzyme production}

For enzyme production in submerged cultures, $1 \times 10^{9}$ spores were transferred to $50 \mathrm{~mL}$ of mineral media (15) containing $0.5 \%$ $(\mathrm{w} / \mathrm{v})$ of one carbon source, and $\mathrm{pH}$ adjusted to 6.0. The cultures were incubated at $28^{\circ} \mathrm{C}$ on a rotary shaker at $120 \mathrm{rpm}$. After 7 days, the mycelia were removed from the culture media by filtration. To determine the dry weight of the mycelia, they were dried overnight at $60^{\circ} \mathrm{C}$. To study the effect of association of different substrates in the production of enzymes, each substrate or mixture of substrates were added to a final concentration of $1 \%(\mathrm{w} / \mathrm{v})$.

\section{Enzyme determinations}

Glycoside hydrolase activities ( $\beta$-glucosidase and $\beta$ xylosidase) were determined by measuring the rate of $\mathrm{p}$ nitrophenol released from the appropriate $\mathrm{p}$-nitrophenyl derivatives ( $p$-nitrophenyl- $\beta$-glucopiranoside and $p$ nitrophenyl- $\beta$-xylopyranoside, respectively). The standard reaction mixture contained $2.0 \mu \mathrm{L}$ of enzyme solution and $1 \mathrm{mg} /$ $\mathrm{mL}$ of substrate in phosphate buffer $0.1 \mathrm{M}, \mathrm{pH}$ 6.0. After $15 \mathrm{~min}$ of incubation at $50^{\circ} \mathrm{C}$, reactions were stopped by the addition of $2 \mathrm{~mL}$ of $0.1 \mathrm{M} \mathrm{Na}_{2} \mathrm{CO}_{3}$ and the p-nitrophenol liberated was determined spectrophotometrically at $410 \mathrm{~nm}$ (22). Polysaccharidase activities (as xylanase, pectinase and carboxymethylcellulase, CMCase) were determined by measuring the amount of reducing sugar (xylose, galacturonic acid and glucose) released from various substrates (xylan, polygalacturonic acid and carboxymethylcellulose, respectively). A $2.0 \mu \mathrm{L}$ volume of enzyme solution was incubated at $50^{\circ} \mathrm{C}$ for $30 \mathrm{~min}$. in $1.0 \mathrm{~mL}$ of substrate solution polysaccharide $(2 \mathrm{mg} /$ $\mathrm{mL}$ ) dissolved in phosphate buffer, $0.1 \mathrm{M}, \mathrm{pH}$ 6.0. Reactions were stopped by the addition of $1 \mathrm{~mL}$ of dinitrosalicylic reagent (14). Tubes were placed in a boiled water bath for $5 \mathrm{~min}$. The $\mathrm{A}_{540 \mathrm{~nm}}$ was read with appropriate single sugars as standards (glucose, xylose and galacturonic acid, respectively to carboxymethylcellulase, xylanase and polygalacturonase activities). Lipase was determined using an olive oil emulsion as substrate. The liberated free fatty acids were titrated with $0.05 \mathrm{M} \mathrm{NaOH}$ and phenolphtalein as indicator (18). Protease was determined using casein as substrate. The released tyrosine was estimated by Lowry's method (12).

\section{Effect of $\mathrm{pH}$ on the activity of xylanase, polygalacturonase and protease}

The effects of $\mathrm{pH}$ on the activity of enzymes were determined in a series of McIlvaine's buffers with $\mathrm{pH}$ values from 3.5 to 8.3 (13), and 0.1 M glycine- $\mathrm{NaOH}$ (pH 8.5 to 10.0).

\section{Effect of temperature on enzyme activity and stability}

The effects of temperature on the activity of enzymes were carried out at temperature ranging from 25 to $70^{\circ} \mathrm{C}$. Thermal stability was investigated by incubating the enzyme at 30,40 ,
50 and $60^{\circ} \mathrm{C}$ for 1 hour. Immediately afterwards the enzymes were immersed in an ice bath and then the activities were tested under standard conditions.

\section{Experimental design and statistical analysis}

To study the effect of each carbon source in the enzyme production, the experimental outline used was a factorial experiment based on $1 \times 13$ block design (one culture time versus 13 different carbon sources) with three repetitions for each one. To study the effect of association of carbon sources in the enzyme production, it was used a $1 \times 10$ block design (one culture time versus 10 different carbon source combination) with three repetitions for each one. The analysis were done using the statistical pack program GraphPad Prism ${ }^{\circledast}$ (3.0). Tukey test $(\mathrm{P}<0.05)$ was applied for comparison of the averages.

\section{Chemicals}

The enzymatic substrates and carbon sources were obtained from Sigma Chemical Corp. (St. Louis, Mo). All other reagents were of analytical grade.

\section{RESULTS}

Enzymes capable of degrading a wide range of glucosides and polysaccharides were detected in cell-free culture supernatants (Table 1). Growth of M. verrucaria on various polysaccharides used as the sole carbon source demonstrated that the fungus secretes enzymes that convert cellulosic, pectinolytic and hemicellulolytic substrates to simple sugars. Glucose and xylose grown cultures did not exhibit polysaccharidase activities, suggesting the presence of simple sugars repressed the production of such enzymes. Among polysaccharide depolimerases, xylanase and polygalaturonase seemed to be the major enzymes secreted by the fungus.

Lipase was barely produced by the fungus when carbohydrates were offered as carbon source. However, its production was increased ten times when the culture medium was enriched with olive oil at 1\% (Table 1). Protease was produced in all cultures and its production was not apparently affected by the carbon source $(\mathrm{P}>0.05)$.

Fig. 1 shows the production of xylanase, pectinase and protease when mixtures of different polymers were used as carbon source. An association of pectin and other carbon source (starch, xylan or casein) increased the production of pectinase from $3.2 \mathrm{U} / \mathrm{mL}$ (cultures using orange pectin as the only carbon source) to 8.1, 7.6, 9.9 and $10.1 \mathrm{U} / \mathrm{mL}$ when starch, casein, xylan and xylan plus casein were added in the pectin cultures, respectively. In fact, the highest levels of three enzymes were obtained in the cultures where wheat bran, a rich substrate containing several carbohydrates and proteins was the carbon source $(12.9,78.3$ and $150 \mathrm{U} / \mathrm{mL}$ to pectinase, xylanase and protease, respectively). 
Table 1. Production of enzymes by M. verrucaria in submerged cultures

\begin{tabular}{lcccccccc}
\hline $\begin{array}{l}\text { Carbon source } \\
(0.5 \%)\end{array}$ & $\begin{array}{c}\text { Biomass } \\
(\mathrm{mg})\end{array}$ & $\begin{array}{c}\beta \text {-glu } \\
(\mathrm{U} / \mathrm{mL})\end{array}$ & $\begin{array}{c}\beta \text {-xyl } \\
(\mathrm{U} / \mathrm{mL})\end{array}$ & $\begin{array}{c}\text { Xylanase } \\
(\mathrm{U} / \mathrm{mL})\end{array}$ & $\begin{array}{c}\text { Pectinase } \\
(\mathrm{U} / \mathrm{mL})\end{array}$ & $\begin{array}{c}\text { CMCase } \\
(\mathrm{U} / \mathrm{mL})\end{array}$ & $\begin{array}{c}\text { Protease } \\
(\mathrm{U} / \mathrm{mL})\end{array}$ & $\begin{array}{c}\text { Lipase } \\
(\mathrm{U} / \mathrm{mL})\end{array}$ \\
\hline Xylose & $58 \pm 7$ & $4.2 \pm 1.3$ & $0.9 \pm 0.1$ & $1.4 \pm 0.5$ & $\mathrm{Nd}$ & $\mathrm{Nd}$ & $45.9 \pm 4.6$ & $0.11 \pm 0.05$ \\
Glucose & $137 \pm 15$ & $8.4 \pm 2.4$ & $1.9 \pm 0.5$ & $1.9 \pm 0.3$ & $\mathrm{Nd}$ & $\mathrm{Nd}$ & $81.4 \pm 11.5$ & $1.23 \pm 0.08$ \\
Maltose & $83 \pm 9$ & $9.1 \pm 2.6$ & $1.5 \pm 0.2$ & $6.1 \pm 0.3$ & $1.3 \pm 0.2$ & $\mathrm{Nd}$ & $58.1 \pm 6.8$ & $0.83 \pm 0.07$ \\
Lactose & $125 \pm 14$ & $7.8 \pm 1.0$ & $1.3 \pm 0.3$ & $14.7 \pm 1.0$ & $\mathrm{Nd}$ & $\mathrm{Nd}$ & $89.0 \pm 9.0$ & $0.52 \pm 0.05$ \\
Cellobiose & $77 \pm 9$ & $8.3 \pm 3.8$ & $3.7 \pm 0.5$ & $7.9 \pm 0.6$ & $1.5 \pm 0.6$ & $0.3 \pm 0.1$ & 56.86 .0 & $0.37 \pm 0.04$ \\
Sucrose & $55 \pm 9$ & $5.1 \pm 1.1$ & $0.9 \pm 0.2$ & $5.4 \pm 0.7$ & $1.2 \pm 0.4$ & $\mathrm{Nd}$ & $35.3 \pm 4.4$ & $0.35 \pm 0.03$ \\
Xylan & $56 \pm 8$ & $18.7 \pm 0.8(*)$ & $15.8 \pm 0.6(*)$ & $26.8 \pm 3.5(*)$ & $2.7 \pm 0.9$ & $0.2 \pm 0.1$ & $33.7 \pm 3.2$ & $0.50 \pm 0.05$ \\
CMcellulose & $21 \pm 3$ & $3.2 \pm 0.3$ & $0.1 \pm 0.04$ & $1.7 \pm 0.2$ & $0.4 \pm 0.04$ & $0.2 \pm 0.04$ & 10.10 .9 & $0.07 \pm 0.01$ \\
Orange pectin & $79 \pm 9$ & $18.0 \pm 2.2(*)$ & $15.1 \pm 1.1(*)$ & $7.7 \pm 2.2$ & $7.7 \pm 0.3(*)$ & $0.3 \pm 0.2$ & $60.2 \pm 4.6$ & $0.36 \pm 0.05$ \\
Starch & $85 \pm 10$ & $7.8 \pm 3.2$ & $3.1 \pm 0.3$ & $7.6 \pm 1.7$ & $3.6 \pm 0.5$ & $\mathrm{Nd}$ & $58.4 \pm 5.4$ & $0.48 \pm 0.05$ \\
Casein & $57 \pm 7$ & $5.2 \pm 2.2$ & $1.3 \pm 0.2$ & $6.9 \pm 1.6$ & $2.4 \pm 0.4$ & $\mathrm{Nd}$ & $33.4 \pm 3.4$ & $0.23 \pm 0.02$ \\
Ovoalbumin & $66 \pm 8$ & $4.0 \pm 1.8$ & $4.1 \pm 0.7$ & $10.4 \pm 4.0$ & $1.3 \pm 0.1$ & $\mathrm{Nd}$ & $43.4 \pm 3.7$ & $0.30 \pm 0.04$ \\
Olive oil & $139 \pm 19$ & $6.6 \pm 2.5$ & $5.0 \pm 0.8$ & $14.2 \pm 1.9$ & $3.3 \pm 0.8$ & $0.5 \pm 0.3$ & 69.55 .8 & $7.42 \pm 0.4(*)$ \\
\hline
\end{tabular}

The cultures were developed at $120 \mathrm{rpm}$ and $28^{\circ} \mathrm{C}$ for 7 days. The results represent the media $\pm \mathrm{SD}$ of three independent experiments. $\mathrm{ND}=$ not detectable activity; $(*)$ significantly different among classes, $\mathrm{p}<0.05$ (Tukey's test); (**) as polygalacturonase activity.

Some properties of the main extracellular enzymes (xylanase, pectinase and protease) from $M$. verrucaria were studied. Xylanase and pectinase was more active in an acidic of $\mathrm{pH}$ (4.55.5 ), while the best $\mathrm{pH}$ for protease activity was between $\mathrm{pH} 8.0$

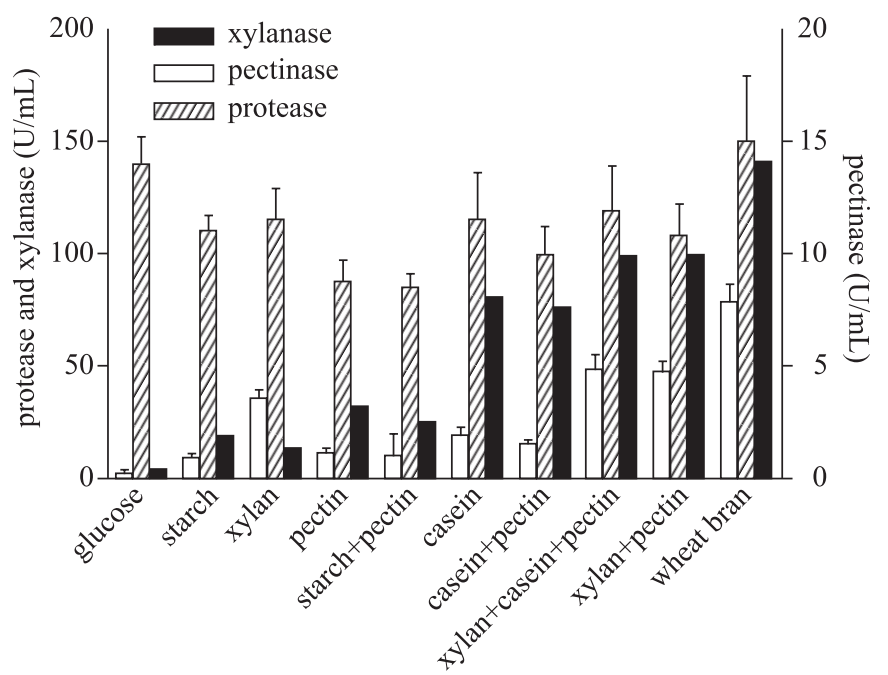

Figure 1. Effect of different mixtures of carbon source in the production of hydrolytic enzymes by Myrothecium verrucaria. The carbon source or mixture of carbon source was added to a final concentration of $0.5 \%(\mathrm{w} / \mathrm{v})$. When more than one carbon source was used, they were used at the same concentration. The cultures were developed at $120 \mathrm{rpm}$ and $28^{\circ} \mathrm{C}$ for 7 days. The results represent the media \pm SD of three independent experiments. and 9.0 (Fig. 2). Fig. 2 suggest the existence of more than one group of protease, one with optimum $\mathrm{pH}$ between 6.0-7.0, and other with optimum $\mathrm{pH}$ between 8.0-9.0. All enzymes were optimally active at $40^{\circ} \mathrm{C}$ and they retained more than $95 \%$ of initial activity after $60 \mathrm{~min}$ at $50^{\circ} \mathrm{C}$ (data not shown).

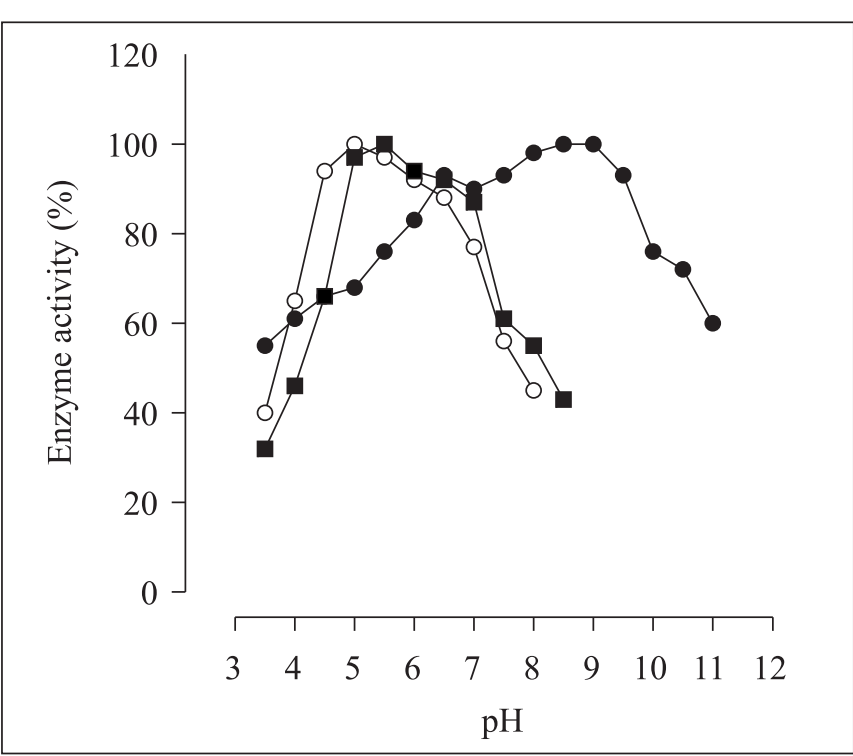

Figure 2. Effect of $\mathrm{pH}$ in the activity of Myrothecium verrucaria enzymes. Pectinase $(\mathrm{O})$, xylanase $(\boldsymbol{\square})$ and protease $(\mathbf{O})$ activities. The $\mathrm{pH}$ curves were done using the substrate for each enzyme in McIlvaine's buffer ( $\mathrm{pH} 3.5$ to 8.3) and $0.1 \mathrm{M}$ glycine buffer ( $\mathrm{pH} 8.5$ to 10.0). 


\section{DISCUSSION}

In the present work we have shown that M. verrucaria produces polysaccharide depolymerases and glucosidases necessary to degrade important structural cell wall polysaccharides, particularly pectin and hemicellulose (Table 1). The secretion of several enzymes provides this phytopathogenic fungus with the ability to attack hosts which differ in their polysaccharide cell wall compositions (22). The secretion of glycosidases combined with the polysaccharide depolymerases may also remove side groups of heteropolysaccharides, making easier the action of endoenzymes (21).

Our results showed the capability of $M$. verrucaria to produce other hydrolytic enzymes such as proteases and lipases. These enzymes may be involved in the capability of the fungus to invade vegetal tissues. $M$. verrucaria protease was identified as an alkaline protease (Fig. 2). However, differently from xylanase and pectinase that were active in a an acidic range of $\mathrm{pH}$, protease from $M$. verrucaria showed high activity at alkaline $\mathrm{pH}$, although it remained active in a large range of $\mathrm{pH}$, what could indicate the presence of multiple isoenzymes, with different optimum $\mathrm{pH}$.

It has been suggested that the proteases may facilitate located penetration of the plant cell wall by breaking down the fibrous glycoproteins that contribute to cell wall stability (2). Some phytopathogenic fungi such as Fusarium, Alternaria, and Rhizoctonia produced serine alkaline proteases, which are indispensable for their growth $(9,19)$. They are probably nutrientmobilizing enzymes whose primary function is the support of fungal growth after host cell death has occurred.

The highest levels of enzymic activities have been obtained when wheat bran was the main substrate (Fig. 1). Wheat bran is a very rich substrate consisting of a mixture of proteins, fat, soluble and insoluble carbohydrates. It is probable that the several hydrolytic enzymes secreted by the fungus present a synergy in the degradation of wheat bran components.

In conclusion, in the present study, it was observed the capability of $M$. verrucaria to produce and secrete different hydrolytic enzymes. Studies of production of enzymes using several plant materials are in progress in our laboratory. This study will serve to increase the understanding of factors that control the production, activity, and the role of $M$. verrucaria hydrolytic enzymes in its phyto-pathogenicity.

\section{ACKNOWLEDGEMENTS}

This work was supported by grants from Conselho Nacional de Desenvolvimento Científico e Tecnológico (CNPq) and Fundação Araucária. R.M. Peralta is research fellow of CNPq. F.G. Moreira is a recipient of CAPES Fellowships. S. Reis is recipient of CNPq Fellowships. We thank Alvina Chaves for her technical assistance.

\section{RESUMO}

\section{Produção de enzimas hidrolíticas pelo fungo fitopatogênico Myrothecium verrucaria em culturas submersas}

A capacidade do fungo fitopatogênico Myrothecium verrucaria produzir enzimas hidrolíticas extracelulares em culturas submersas foi estudada utilizando diversos substratos. O fungo foi capaz de produzir diferentes depolimerases e glicosidases, sendo xilanases, pectinases e proteases as mais importantes. Atividade lipase foi encontrada nos filtrados das culturas desenvolvidas na presença de óleo de oliva, enquanto atividade proteolítica foi detectada em todas as culturas. Xilanase e pectinase foram otimamente ativas em $\mathrm{pH}$ 4,5 a 5,5, enquanto protease foi ativa em ampla faixa de $\mathrm{pH}(3,5$ a 11,0). As três enzimas foram otimamente ativas $40^{\circ} \mathrm{C}$ e estáveis por várias horas a temperaturas até $50^{\circ} \mathrm{C}$.

Palavras-chave: carboidrases, enzimas hidrolíticas, Myrothecium verrucaria, protease

\section{REFERENCES}

1. Baer, D.; Gudmestad, N.C. In vitro cellulolytic activity of the plant pathogen Clavibacter michiganensis subsp. sepedonicus. Can. J. Microbiol., 877-888, 1995.

2. Carpita, N.C.; Gibeaut, D.M. Structural models of primary cell walls in flowering plants: consistency of molecular structure with the physical properties of the walls during growth. Plant J., 3, 1-10, 1993.

3. De Romano, A.B. Myrothecium verrucaria (Alb. Y Scw.) nuevo patogeno del girasol. Sunfl. Newsl., 3, 8-10, 1979.

4. Dobinson, K.F.; Lecomte, N.; Lazarovits, G. Production of an extracelular trypsin-like protease by the fungal plant pathogen Verticillium dahliae. Can. J. Microbiol., 43, 227-233, 1996.

5. Faheild, S.M.M.; Murad, H.A. Utilization of polygalacturonase from Myrothecium verrucaria for maceration of orange pupl. Deustche Lebensmittel-Rundschau., 88, 117-119, 1992.

6. Farr, D.F.; Bills, G.F.; Chamuris, G.P.; Rossman, A.Y. Fungi on Plants and Plant Products in the United States. American Phytopathological Society, St. Paul, Minn, 1989

7. Filho, E.F.X.; Puls, J.; Coughlan, M.P. Physicochemical and catalytic properties of a low molecular weight endo 1,4 $\beta$-xylanase from Myrothecium verrucaria. Enz. Microbiol. Technol., 15, 535-540, 1994.

8. Govindsamy, V.; Gunaratna, K.R.; Balasubramanian, R. Properties of extracellular chitinase from Myrothecium verrucaria, an antagonist to the groundnut rust Puccinia arachidis. Can. J. Plant Pathol., 20, 62-68, 1998

9. Griffin, D.H. Fungal physiology. Wiley-Liss John Wiley \& Sons, Inc. Publ, 1994.

10. Guo, J.; Liang, X.X.; Mo, P.S.; Li, G.X. Purification and properties of bilirrubin oxidase from Myrothecium verrucaria. Appl. Biochem. Biotechnol., 31, 135-143, 1991.

11. Heyn, A.N.J. The occurrence of Myrothecium on field cotton. Text. Res. J., 28, 44-445, 1958.

12. Lowry, O.H.; Rosebrough, N.J.; Farr, A.L.; Randall, R.L. Protein measurement with the Folin phenol reagent. J. Biol. Chem., 193, 265-274, 1951 . 
13. Morita, T.; Assumpção, R.M.V. Manual de soluções, reagentes e solventes. 2a edição. Editora Edgard Blucher Ltda, 1972, p. 275.

14. Miller, L. Use of dinitrosalicylic acid reagent for determination of reducing sugars. Anal. Chem., 31, 426-428, 1959.

15. Montenecourt, B.S., Eveileigh, D.E. Preparation of mutants of Trichoderma reesei with enhanced cellulase production. Appl., Environ. Microbiol., 34, 777-784, 1977

16. Nguyen, T.H.; Mathur, S.B.; Neergaard, P. Seed-borne species of Myrothecium and their pathogenic potential. Trans. Br. Mycol. Soc., 61, 347-354, 1973.

17. North, M.J. Comparative biochemistry of the proteinases of eucaryotic microorganisms. Microbiol. Rev., 46, 308-340, 1982.

18. Park, Y.K.; Pastore, G.M.; de Almeida M.M. Hydrolysis of soybean oil by a combined lipase system. JAOCS, 65, 252-254, 1988.

19. Pekkarinen, A.; Mannonen, L.; Jones, B.L.; Niku-Paavola, M.-L. Production of proteases by Fusarium species grown on barley grains and in media containing cereal proteins. J. Cereal Sci., 31, 253-261, 2000.

20. Raymond, F.L.; Etchells, J.L.; Bell, T.A.; Masley, P.M. Filamentous fungi from blossoms ovaries, and fruit of pickling cucumbers. Mycologia., 51, 492-511, 1959.
21. Ries, S.M., and Albersheim, P. Purification of a protease secreted by Colletotrichum lindemuthianum. Phytopathology., 63, 625-629, 1973.

22. Riou, C.; Freyssinet, G.; Fevre, M. Production of cell wall-degrading enzymes by the phytopathogenic fungus Sclerotinia sclerotiorum. Appl. Environ. Microbiol., 57, 1478-1485, 1991.

23. Ryan, C.A. Proteolytic enzymes and their inhibitors in plants. Аnпи. Rev. Plant Physiol., 24, 173-196, 1973.

24. Singh, M.; Aujla, S.S. Myrothecium verrucaria Ditm. Ex Fr. On rice in Punjab. Rev. Appl. Mycol., 46, 368-375, 1967.

25. Stevenson, J.A.; McColloch, L.P. Myrothecium as a tomato fruit organism. Plant Dis. Rep., 31, 147-149, 1947.

26. Vyas, P.; Deshpande, M.V. Purification and characterization of an endochitinase from Myrothecium verrucaria. J. Gen. Appl. Microbiol., 39, 91-99, 1993.

27. Yang, S.M.; Jong, S.C. Host range determination of Myrothecium verrucaria isolated from leafy spurge. Plant Disease., 79, 994-997, 1995. 